\title{
Industry 4.0: Theoretical Foundations and the Strategic Priorities of Russian Regions
}

\author{
Marina Kurnikova \\ Chair for Regional Economy and Development \\ Samara State University of Economics \\ Samara, Russia \\ mvkurnikova@gmail.com
}

Sergey Bolgov

Chair for Management and Logistics at Transport Samara State Transport University

Samara, Russia

bolgov@vostok-invest.ru

\author{
Elena Bolgova \\ Chair for Regional Economy and Development \\ Samara State University of Economics \\ Samara, Russia \\ elena_bolgova@rambler.ru
}

\author{
Valeriy Khaitbaev \\ Chair for Management and Logistics at Transport \\ Samara State Transport University \\ Samara, Russia \\ vhaitbaev21@mail.ru
}

\author{
Irina Dodorina \\ Chair for Management and Logistics at Transport \\ Samara State Transport University \\ Samara, Russia \\ dodorina@mail.ru
}

\begin{abstract}
The Industry 4.0 concept acts as a theoretical foundation for introducing digital technologies into production and management processes which leads to the digital transformation of economy including the one at the level of territories. The efficiency of digital transformation in developed and developing countries is achieved through public administration - the development of government programmes, national and local strategies, the plans and projects of a certain region. The current practices for strategic planning need a scientifically-based justification of development priorities and their overarching presence in a comprehensive system of strategic documents. The difficulty of developing digital transformation priorities arises from the ongoing research into Industry 4.0 concept deriving from the dynamically changing trends of digitalization, its diversity and complexity for the development of Russian regions. The prepared Russian documents fail to reflect the priority of universities in creating Industry 4.0, with a "digital university" being the only model in working out, implementing and using digital technologies in regional economies. Due to the incomplete Industry 4.0 concept and the urgency of the digital transformation of the economy, the paper is aimed at developing theoretical foundations of the «datadriven» economy. The research conducted by the authors involved the dialectic method, the methods of summarization, analysis and synthesis, deduction and induction. The study resulted in some certain suggestions on strategic priorities for the development of Russian regions in view of key digital
\end{abstract}

technologies, the role of universities in their creation and implementation. The authors have shown that Industry 4.0 has a huge potential in setting priorities of digital economy and management at the level of regions. 4.0

Keywords: region, digitalization, strategic priorities, Industry

\section{INTRODUCTION}

The current state policy of the Russian Federation associates the innovative development of the country with digital transformation - the process of creating, distributing and using information and communication technologies (ICT). This process results in the creation of the digital economy that is the form of economic activity transforming the markets and business environment, regional economies and the framework of local development into digital and smart systems. The importance of digital transformation is pointed out in the Message of the President of the Russian Federation to the Federal Assembly dated 2016, in the strategies for scientific and technological development and the development of the information society [1]. The national project "Digital Economy" brings regulatory framework and mechanisms of digital environment, information infrastructure, the system of training and the level of information security in line with the stated goals [2]. At the local level, the digital paradigm of 
innovative development provides for the spread of digital platforms and technologies in regional economies, the practices of public and municipal administration. The largescale digital transformations result in the regional economies of a new technological generation and require a reprioritization. The scientific basis for the development of new priorities is set by the Industry 4.0 concept which theoretical foundations need systematization and further development in compliance with the prospects of their practical use in the strategic planning of Russian subjects.

\section{LITERATURE OVERVIEW}

The concept of Industry 4.0 derives from the German strategic initiative developed in 2011 to respond to the challenges of national industries due to the fourth industrial revolution [3]. Furthermore, the term was used in the studies of the new business models of industrial enterprises allowing to significantly improve their present competitive position, increasing value creation and minimizing risks [4]. The researchers point out such features of Industry 4.0 as the high level of automatization achieving a higher level of operational productivity and efficiency [5] and connecting the physical to the virtual world [6], achieved through 12 key digital technologies and resulted from the digital transformation of the economy.

Conceptually, Industry 4.0 introduces new conditions for the economic development, with information being the most important factor of production ("the new oil"), which leads to the need of their reflection in long-term priorities of local socio-economic systems.

1) The authors of the concept state that data would attain a higher importance in the economy than hydrocarbons. They use the term a «data-driven» economy when describing this new stage of economic development $[7,8,9]$.

2) In a "data-driven" economy the digitalization is a key factor of development not only for businesses and industries, but also for separate territories (countries, subnational entities, cities).

3) The digitalization is strengthened through the development of government programmes, national and local strategies, the plans and projects of a certain region. Being a leader of industrialization in Europe, Germany was the first country to set Industry 4.0 as the goal of a certain state programme aiming at the collaboration of business and the government for the sake of preserving and increasing the competitive potential of the country and its federal states. The developing countries (China, India, Brazil, etc.) are working out their own national strategies aimed at the development of Industry 4.0. Both in developed and developing countries, the vector of Industry 4.0 is kept through the industrial policies, local programmes aimed at the increase in the scientific and technological potential, the improvement of an innovative system. In such programs, the main goal is the improved competitiveness of the territory through high-quality renewal of the technological basis of traditional industries, mainly in the manufacturing sector, as well as the accelerated development of technology-intensive production. The main social task of such programmes is the formation of a new social mindset, with new ideas being of the highest value [10, $11,12]$.

4) The development of technologies in Industry 4.0 results in the transformation of global economic geography and the shift of growth to the centers of concentration (development and usage) of breakthrough technologies. The uneven development of breakthrough technologies leads to the formation of a new system of geographic centers including the ones around leading entrepreneurial universities uniting the researchers and developers of breakthrough technologies, as well as the creators and customers of flagship products and services, therefore increasing competition for traditional industrial regions from new centers of breakthrough technologies.

5) In municipal development, Industry 4.0 contributes to the growth in the intellectual potential of cities. The transformation of urban agglomerations into innovative business subjects results from the global character of production in the data-driven economy, the development of Cyber-Physical Production Systems (CPPS) and the Internet of Things (IOT) together with their related services. The implementation of innovations in advanced production techniques and logistics is achieved through new hardware, sensors and software architecture necessary for managing production processes and logistics networks at a level of the world standards. Totally new solutions of a smart city including the services via internet applications have accelerated the pace of urban agglomerations and large cities $[13,14,15]$.

\section{MethodOlOGY AND MethodS}

The research involved the method of a theoretical analysis of the concept of Industry 4.0 in order to identify the conditions of local development resulted from the data-driven economy and the digital paradigm of local entities development. The method of summarization was used to describe the features of Industry 4.0, its key technologies, the directions of digital transformation of the economy needed to be included into regional strategic priorities. The dialectic method helped to assess the content of Russian regional strategic priorities (based upon the example of the Samara region) in conjunction with the directions of digital transformation of the economy and digital technologies of Industry 4.0. The methods of analysis and synthesis, deduction and induction were used to work out the priorities suggested to include into the strategies of social and economic development of Russian subjects in the context of digital transformation of regional digital economies and the practices of public and municipal administration.

\section{RESUlTS AND THEIR APPLICATION}

\section{A. Regional strategic priorities: the direction of the digital transformation of economies}

The content analysis of the strategic documents of Russian subjects revealed that their goals and objectives reflect longterm regional priorities. According to the current methodical tools, the justification of regional priorities is based upon concepts, strategies, forecasts of the Russian Federation and 
TABLE I. THE DIRECTIONS OF ECONOMIC TRANSFORMATION IN

its federal districts [16]. The qualitative indicators of priorities reflect the directions of the public policy aimed at regional growth, international practices of developing industrial clusters, world trends in the socio-economic development. While preparing the documents, the diagnostics of the current state of regional economy, its competitiveness is conducted, the conditions and prospects of its development are studied. The validity of the chosen priorities is achieved through SWOT-analysis, expert and trend prognosis, results framework and horizons of achieving priorities under different scenarios. As the case-study of the Samara region in developing strategic priorities shows, the directions of economic transformation in the framework of the Industry 4.0 concept are found in the chapter of the strategy devoted to the description of world trends of socio-economic development (see Table I).

The matrix presented in Table I shows a high correlation between the regional strategic priorities of the Samara Region and the directions of economic transformation in Industry 4.0 achieved through high socio-economic and spatial potential of the region.
INDUSTRY 4.0 AND THE STRATEGIC PRIORITIES OF THE SAMARA REGION ${ }^{\text {A }}$

\begin{tabular}{|c|c|c|c|c|c|}
\hline \multirow[b]{2}{*}{$\begin{array}{c}\text { The } \\
\text { direction } \\
\text { s of } \\
\text { economic } \\
\text { transfor } \\
\text { mation }\end{array}$} & \multicolumn{5}{|c|}{ Industry 4.0} \\
\hline & $\begin{array}{c}\text { digitalizat } \\
\text { ion of } \\
\text { productio } \\
n[10]\end{array}$ & $\begin{array}{c}\text { decentrali } \\
\text { zation of } \\
\text { productio } \\
n \\
\text { processes } \\
{[11]}\end{array}$ & $\begin{array}{c}\text { vertical } \\
\text { and } \\
\text { horizontal } \\
\text { integratio } \\
n \text { of } \\
\text { added } \\
\text { value } \\
\text { chains } \\
\text { [12] } \\
\end{array}$ & $\begin{array}{c}\text { increase } \\
\text { in labour } \\
\text { productivi } \\
\text { ty }[12]\end{array}$ & $\begin{array}{c}\text { flexibility } \\
\text { in } \\
\text { managem } \\
\text { ent [12] }\end{array}$ \\
\hline $\begin{array}{l}\text { increased } \\
\text { competiti } \\
\text { veness of } \\
\text { the } \\
\text { economy }\end{array}$ & $\begin{array}{l}\text { the } \\
\text { developm } \\
\text { ent of the } \\
\text { ICT } \\
\text { sector; } \\
\text { digital } \\
\text { transform } \\
\text { ation of } \\
\text { industries } \\
\text { and } \\
\text { sectors }\end{array}$ & $\begin{array}{l}\text { entrepren } \\
\text { eur- } \\
\text { centric } \\
\text { business } \\
\text { environm } \\
\text { ent }\end{array}$ & $\begin{array}{l}\text { diversific } \\
\text { ation and } \\
\text { customiz } \\
\text { ation of } \\
\text { IT- } \\
\text { services }\end{array}$ & $\begin{array}{l}\text { investme } \\
\text { nt in IT } \\
\text { infrastruc } \\
\text { ture } \\
\text { (Electroni } \\
\text { c } \\
\text { Highway } \\
\text { s) }\end{array}$ & $\begin{array}{l}\text { enhanced } \\
\text { efficiency } \\
\text { of } \\
\text { developm } \\
\text { ent } \\
\text { institutes }\end{array}$ \\
\hline $\begin{array}{l}\text { improve } \\
\text { ment in } \\
\text { the } \\
\text { quality of } \\
\text { life for } \\
\text { the } \\
\text { citizens }\end{array}$ & $\begin{array}{l}\text { creation } \\
\text { of digital } \\
\text { society }\end{array}$ & $\begin{array}{l}\text { collaborat } \\
\text { ion with } \\
\text { local } \\
\text { authoritie } \\
\text { s }\end{array}$ & $\begin{array}{l}\text { creation } \\
\text { of new } \\
\text { high- } \\
\text { quality } \\
\text { jobs; } \\
\text { efficient } \\
\text { employm } \\
\text { ent policy }\end{array}$ & $\begin{array}{l}\text { improve } \\
\text { ment of } \\
\text { professio } \\
\text { nal } \\
\text { competen } \\
\text { ces of } \\
\text { populatio } \\
\text { n }\end{array}$ & $\begin{array}{l}\text { improved } \\
\text { quality of } \\
\text { public } \\
\text { services }\end{array}$ \\
\hline $\begin{array}{l}\text { enhancin } \\
\mathrm{g} \\
\text { efficiency } \\
\text { in the } \\
\text { Governm } \\
\text { ent }\end{array}$ & $\begin{array}{l}\text { E- } \\
\text { governme } \\
\text { nt }\end{array}$ & $\begin{array}{l}\text { SME } \\
\text { support }\end{array}$ & $\begin{array}{l}\text { public- } \\
\text { private } \\
\text { partnershi } \\
\text { p }\end{array}$ & $\begin{array}{l}\text { improved } \\
\text { efficiency } \\
\text { of } \\
\text { budget, } \\
\text { investme } \\
\text { nt and } \\
\text { innovativ } \\
\text { e policy }\end{array}$ & $\begin{array}{l}\text { reduction } \\
\text { of } \\
\text { administr } \\
\text { ative } \\
\text { barriers }\end{array}$ \\
\hline $\begin{array}{l}\text { spatial } \\
\text { developm } \\
\text { ent }\end{array}$ & $\begin{array}{l}\text { high-tech } \\
\text { technopar } \\
\mathrm{k} \\
\text { "Zhigule } \\
\text { vskaya } \\
\text { Dolina" }\end{array}$ & $\begin{array}{l}\text { diversific } \\
\text { ation of } \\
\text { economie } \\
\text { s of cities } \\
\text { located } \\
\text { within } \\
\text { the } \\
\text { Samara- } \\
\text { Togliatti } \\
\text { agglomer } \\
\text { ation }\end{array}$ & $\begin{array}{l}\text { the single } \\
\text { standard } \\
\text { of } \\
\text { interactio } \\
\mathrm{n} \text { with } \\
\text { investors } \\
\text { for the } \\
\text { cities } \\
\text { located } \\
\text { within } \\
\text { the } \\
\text { Samara- } \\
\text { Togliatti } \\
\text { agglomer } \\
\text { ation }\end{array}$ & $\begin{array}{l}\text { the } \\
\text { system of } \\
\text { industrial } \\
\text { parks }\end{array}$ & $\begin{array}{l}\text { new } \\
\text { administr } \\
\text { ative } \\
\text { bodies of } \\
\text { coordinat } \\
\text { ing and } \\
\text { managing } \\
\text { the } \\
\text { developm } \\
\text { ent of the } \\
\text { Samara- } \\
\text { Togliatti } \\
\text { agglomer } \\
\text { ation }\end{array}$ \\
\hline \multicolumn{6}{|c|}{$\begin{array}{l}\text { arked out by the authors according to: The Strategy of the socio- } \\
\text { economic development of the Samara Region until 2030, } \\
\text { http://docs.cntd.ru/document/450278243; } \\
\text { The strategy of ICT development in the Samara Region until } 2020 \text { and a } \\
\text { perspective up to 2025, http://docs.cntd.ru/document/464006633; } \\
\text { The Government programme of the Samara Region "The development } \\
\text { of ICT infrastructure of the Samara Region" for 2014-2021, } \\
\text { http://docs.cntd.ru/document/464006633 }\end{array}$} \\
\hline
\end{tabular}


TABLE II. GEOGRAPHIC DISTRIBUTION OF THE TOP 3 MASTER'S PROGRAMS IN THE EDUNIVERSAL BEST MASTERS RANKING IN GERMANY IN THE 2018/2019 ACADEMIC YEAR ${ }^{A}$ economy, digital society development, public and municipal administration

The key digital technologies suggested by the Industry 4.0 concept were firstly presented as the long-term priorities in the strategy for the development of the information society in the Russian Federation. They are aimed at creating the society where the level of information availability and accessibility is the key factor of the quality of life for the citizens and the increase in economic competitiveness. The later adopted national programme and national project of digital economy specify the spheres and scope of state involvement into the creation, implementation, distribution of national ICT in Russian economy, budget expenses for realizing the priorities [2]. The case-study of the Samara Region confirms that regional strategic documents specify the regional component of digital technologies implementation, the creation of ICT infrastructure according to the industrial specialization and provided by the resource capacity of the regional economy (see Table II).

\section{RESUltS AND THEIR APPLICATION}

The achievement of strategic priorities of Industry 4.0 in Russian regions is resulted from the intellectual potential of digital transformation and the role of universities in its creation. The strategic documents specify the following functions of universities: a) educative (the preparation of 120,000 graduates in the sphere of informatization, the education of $10 \mathrm{mln}$ people at online-programs of digital literacy); b) research (the financial support of 1350 pcs of business-oriented scientific and technological projects in digital technologies); c) the implementation of the "digital university" model in 100 per cent of Russian state-owned universities [2].

\begin{tabular}{|c|c|c|c|c|c|}
\hline \multirow[b]{2}{*}{$\begin{array}{c}\text { Key } \\
\text { digital } \\
\text { technolo } \\
\text { gies of } \\
\text { Industry } \\
4.0 \text { [7] }\end{array}$} & \multicolumn{5}{|c|}{ Strategic documents } \\
\hline & $\begin{array}{c}\text { The } \\
\text { strategy } \\
\text { for the } \\
\text { developm } \\
\text { ent of } \\
\text { informati } \\
\text { on society } \\
\text { in the } \\
\text { Russian } \\
\text { Federatio } \\
\text { n in } 2017- \\
2030\end{array}$ & $\begin{array}{c}\text { The } \\
\text { National } \\
\text { Program } \\
\text { me"Digit } \\
\text { al } \\
\text { Economy } \\
\text { of the } \\
\text { Russian } \\
\text { Federatio } \\
n ”\end{array}$ & $\begin{array}{c}\text { The } \\
\text { Strategy } \\
\text { of the } \\
\text { socio- } \\
\text { economic } \\
\text { developm } \\
\text { ent of the } \\
\text { Samara } \\
\text { Region } \\
\text { until 2030 }\end{array}$ & $\begin{array}{c}\text { The } \\
\text { strategy } \\
\text { of ICT } \\
\text { developm } \\
\text { ent in the } \\
\text { Samara } \\
\text { Region } \\
\text { until 2020 } \\
\text { and a } \\
\text { perspectiv } \\
\text { e up to } \\
2025\end{array}$ & $\begin{array}{c}\text { The } \\
\text { Governm } \\
\text { ent } \\
\text { program } \\
\text { me of the } \\
\text { Samara } \\
\text { Region } \\
\text { "The } \\
\text { developm } \\
\text { ent of } \\
\text { ICT } \\
\text { infrastruc } \\
\text { ture of } \\
\text { the } \\
\text { Samara } \\
\text { Region" } \\
\text { for } 2014 \text { - } \\
2021\end{array}$ \\
\hline $\begin{array}{l}\text { big data } \\
\text { and } \\
\text { analytics }\end{array}$ & + & + & + & + & - \\
\hline $\begin{array}{l}\text { autonomo } \\
\text { us robots }\end{array}$ & + & - & + & - & - \\
\hline $\begin{array}{l}\text { simulatio } \\
\mathrm{n}\end{array}$ & + & + & + & - & \\
\hline $\begin{array}{l}\text { horizonta } \\
1 \text { and } \\
\text { vertical } \\
\text { system } \\
\text { integratio } \\
\mathrm{n}\end{array}$ & + & + & + & + & + \\
\hline $\begin{array}{l}\text { internet } \\
\text { of things } \\
\text { (IoT) } \\
\text { (includin } \\
\mathrm{g} \\
\text { sensors) }\end{array}$ & + & + & + & + & + \\
\hline $\begin{array}{l}\text { cyber- } \\
\text { security }\end{array}$ & + & + & + & + & + \\
\hline the cloud & + & + & + & + & - \\
\hline $\begin{array}{l}\text { additive } \\
\text { manufact } \\
\text { uring }\end{array}$ & + & - & + & - & - \\
\hline $\begin{array}{l}\text { augmente } \\
\text { d reality }\end{array}$ & + & + & + & - & - \\
\hline $\begin{array}{l}\text { artificial } \\
\text { intelligen } \\
\text { ce }\end{array}$ & + & + & + & + & + \\
\hline $\begin{array}{l}\text { mobile } \\
\text { technolog } \\
\text { ies }\end{array}$ & + & + & + & + & + \\
\hline $\begin{array}{l}\text { RFID and } \\
\text { RTLS } \\
\text { technolog } \\
\text { ies }\end{array}$ & + & + & + & + & + \\
\hline
\end{tabular}

The theoretical foundations of the Industry 4.0 and the practices of their use in developed countries reveal the fact that the role of universities should be viewed as the centers of spatial concentration uniting researchers and developers of breakthrough technologies, as well as specialists in introducing and using key digital technologies. According to 
the experts, the first step to the development of universities within the system of geographic centers of digitalization is based upon the need of introducing big data and analytics, additive manufacturing, augmented reality into manufacturing sectors, which results in a large number of new opportunities for regional companies and industries. The second step is the understanding of "weak spots" and advantages of the application, development, implementation and distribution of digital technologies in productional and managerial tasks, the necessity to expand the list of technologies. The third step is the use of digital technologies in public and municipal administration at the level standards of digital economy [17]. The lack of knowledge is the main barrier in steady implementation of those steps. The way of overcoming this barrier involves the development of "Industry 4.0 educational factories" - scientific and research laboratories of a new type similar to a real productional environment (Smart Production Lab (SPL). The SPL modules include a) Cyber-Phys-systems (D) - various kinds of digital technologies, b) Methodologsystems (Y) - scientific methodology of their use; c) LF utilities - customers (end-users of project results). SPL is a platform of collaboration between students, researchers and practitioner enabling to create a new knowledge on request of businesses within the formal strategic cooperation of large businesses, SME and universities. The difference from traditional scientific and research laboratories is that SPL are in the framework of the "digital university" concept at the level of research and implementation functions and creates LF utilities - the fully completed projects of "smart production", "smart factory", "smart railway", as well as new variants of digital design, the need in which is only being formed. Public and municipal bodies can be LF for SPL developing the projects of a "smart city", "smart region", models of egovernment. The collaboration with LF in services generates a flow of orders, identifies strategic priorities of universities in realizing educational programmes. The efficiency of creating SPL and the results of their activities prove the urgency of their introduction into regional documents of strategic planning, the development priorities of educational system and staffing economic growth, the priorities of industries and ICT infrastructure development.

\section{CONCLUSION}

This paper casts light on the position of the industry 4.0 concept in the documents of strategic planning in Russian regions. The analysis conducted by the authors showed that the scientific foundations of the data-driven economy are used to justify the long-term priorities of Russian regions. Yet, we can also draw some important generic conclusions from the theory and practice of digital transformation in Russian regions.

First, the analysis showed that the scope of priorities includes increased competitiveness of the economy, improvement in the quality of life for the citizens, enhancing efficiency in the government and spatial development.

Second, the content analysis resulted in conclusion of the cross-cutting nature of priorities in national and regional documents.
Third, in plans, projects and programmes of digitalization the introduction of digital technologies is viewed as the factor of regional socio-economic development. However, the identified connections between regional strategic priorities and the ones of the digital transformation of the economy do not involve the opportunities of universities.

The findings presented in this paper suggest that Russian regional universities would play the role of the centers of spatial concentration of research, development, implementation and use of key digital technologies in the framework of the SPL organizational model. Due to its high efficiency, the authors suggest to reflect the number of such laboratories and their results among the priorities of the education system, industrial and infrastructure development in the strategic documents of Russian subjects.

\section{REFERENCES}

[1] "Message of the President of the Russian Federation to the Federal Assembly dated 2016". Available at: http://kremlin.ru/events/president/news/53379 (Accessed: 30 April 2019).

[2] Information materials on the national programme "Digital economy of the Russian Federation". Available at: http://static.government.ru/media/files/3b1AsVA1v3VziZip5VzAY8RT cLEbdCct.pdf (Accessed: 30 April 2019).

[3] B. Vogel-Heuser and D. Hess, "Guest editorial Industry 4.0prerequisites and visions", IEEE Transactions on Automation Science and Engineering, 2016, vol. 13 (2), pp. 411-413.

[4] W.W.H. Kagermann, and J. Helbig, "Recommendations for implementing the strategic initiative Industrie 4.0". Available at: http://www. acatech.de/fileadmin/user_upload/Baumstruktur _ nach _ Website/Acatech/ root/de/Material _ fuer_Sonderseiten/Industrie 4.0/Final _ report _ _ Industrie _ 4. $0_{\text {_ }}$ accessible.pdf (Accessed: $0 \overline{1}$ October 2019).

[5] Y. Lu, "Industry 4.0: A survey on technologies, applications and open research issues", J. Ind. Information Integr., 2017, vol. 6, pp. 1-10. DOI: 10.1016/j.jii.2017.04.005.

[6] "Matching Relationship? An analysis of selected Industry 4.0 models", 2017 Federal Conference on Computer Science and Informatics Systems (FedCSIS), Prague, 11, 2017, pp. 989-993. DOI: https://doi.org/10.15439/2017F365.

[7] M. Ruessmann, P. Lorenz, M. Gerbert, J. Waldner, P. Justus, and M. Engel, "Industry 4.0: The Future of Productivity and Growth in Manufacturing Industries", Boston Consulting Group, 2015.

[8] C. Salkin, M. Oner, A. Ustundag and E. Cevikcan, "A conceptual framework for Industry 4.0", In: Ustundag, A. and Cevikcan, E. Industry 4.0: Managing The Digital Transformation, Springer Series in Advanced Manufacturing, Springer, 2018.

[9] J.A. Sauncedo-Martínez, M. Pérez-Lara, J.A. Marmolejo-Saucedo, T.E. Salais-Fierro, and P. Vasant, "Industry 4.0 framework for management and operations: A review", Journal of Ambient Intelligence and Humanized Computing, 2018, vol. 9 (3), pp. 789-801.

[10] European Commission, 2017. "Key lessons from national industry 4.0 policy initiatives in Europe", Digital Transformation Monitor, European Commission, Brussels, Belgium.

[11] UNDP, "Development 4.0: Opportunities and Challenges for Accelerating Progress towards the Sustainable Development Goals in Asia and the Pacific", Sustainable Development Series, UN Development Programme, New York, NY, USA, 2018.

[12] BMBF, "Industrie 4.0. Innovationen für die Produktion von morgen, Die neue Hightech Strategy. Innovationen für Deutschland", Bundesministerium für Bildung und Forschung, Berlin, Germany, 2017. 
[13] M. Loi and P.O. Dehaye, "If Data Is The New Oil, When Is The Extraction of Value From Data Unjust?". Available at: https://www.researchgate.net/publication/326200389_If_Data_Is_The_ New_Oil_When_Is_The_Extraction_of_Value_From_Data_Unjust (Accessed: 01 October 2019).

[14] M. Speringer, "Differentiation of Industry 4.0 Models. The 4th Industrial Revolution from different Regional Perspectives in the Global North and Global South". Available at: https://www.researchgate.net/publication/332762483_Differentiation_of _Industry_40_Models_The_4th_Industrial_Revolution_from_different_ Regional_Perspectives_in_the_Global_North_and_Global_South (Accessed: 01 October 2019).
[15] M. K. Tiwari, "Requirements for and Impacts of ICT based Advanced Manufacturing with special Reference to the international Context. Kharagpur". Available https://www.researchgate.net/profile/Manoj_Tiwari4 (Accessed: 01 October 2019).

[16] Federal Law no. 172-FZ "On Strategic Planning in the Russian Federation". Available at: http://base.garant.ru/70684666 (Accessed: 01 October 2019).

[17] M. Nardello, O. Madsen, and Ch. Møller, "The Smart Production Laboratory: A Learning Factory for Industry 4.0". Available at: https://vbn.aau.dk/ws/portalfiles/portal/271545492/b32ae52d736cc3cff8 0ad5da2a5b66a72cff.pdf (Accessed: 01 October 2019). 